\title{
High-Temperature Requirement A1 Protease as a Rate-Limiting Factor in the Development of Osteoarthritis
}

\author{
Peter H. Chen, ${ }^{*}$ Tian Tang,${ }^{* \dagger}$ Chenlu Liu,${ }^{* \dagger}$ Beiyu Wang,${ }^{* \ddagger}$ Michelle Mian, ${ }^{*}$ Chio Oka, ${ }^{\S}$ Maria Baquerizo, ${ }^{*}$ Yefu Li, ${ }^{* \Phi}$ and \\ Lin $X u^{*} \pi$
}

From the Department of Developmental Biology, * Harvard School of Dental Medicine, Boston, Massachusetts; the Department of Orthodontics, ${ }^{\dagger}$ State Key Laboratory of Oral Diseases, National Clinical for Oral Diseases, West China Hospital of Stomatology, and the Department of Orthopedic Surgery, ${ }^{\ddagger}$ West China Hospital, Sichuan University, Chengdu, China; the Division of Gene Function in Animals, ${ }^{\S}$ Nara Institute of Science and Technology, Ikoma, Japan; and the Faculty of Medicine, "Harvard Medical School, Boston, Massachusetts

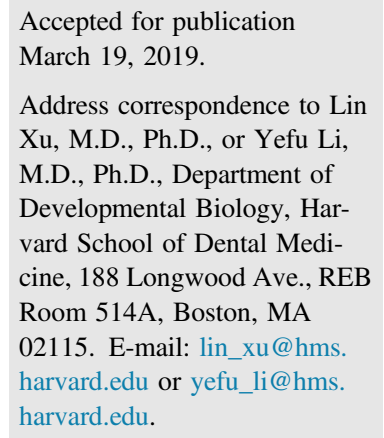

\begin{abstract}
Preserving the mature articular cartilage of joints is a critical focus in the prevention and treatment of osteoarthritis. We determined whether the genetic inactivation of high-temperature requirement A1 (HtrA1) can significantly attenuate the degradation of articular or condylar cartilage. Two types of mouse models of osteoarthritis were used, a spontaneous mutant mouse model [type XI collagen -haploinsufficient (Col11a1 ${ }^{+/-}$) mice] and two post-traumatic mouse models [destabilization of the medial meniscus (DMM) on the knee and a partial discectomy (PDE) on the temporomandibular joint]. Three different groups of mice were generated: i) HtrA1 was genetically deleted from Col11a1 ${ }^{+/-}$mice $\left(\mathrm{HtrA1}^{-/-}\right.$;Col11a1 $\left.{ }^{+/-}\right)$, ii) HtrA1-deficient mice $\left(\mathrm{HtrA1}^{-/-}\right)$were subjected to DMM, and iii) HtrA1 ${ }^{-/-}$ mice were subjected to PDE. Knee and temporomandibular joints from the mice were characterized for evidence of cartilage degeneration. The degradation of articular or condylar cartilage was significantly delayed in $\mathrm{HtrA1}^{-/-}$; Col11a1 ${ }^{+/-}$mice and $\mathrm{HtrA1}^{-/-}$mice after DMM or PDE. The amount of collagen type VI was significantly higher in the articular cartilage in $\mathrm{HtrA}^{-/-} ; \mathrm{Col}_{11 \mathrm{a} 1^{+/-}}$mice, compared with that in Col11a1 ${ }^{+/-}$mice. The genetic removal of HtrA1 may delay the degradation of articular or condylar cartilage in mice. (Am J Pathol 2019, 189: 1423-1434; https://doi.org/10.1016/ j.ajpath.2019.03.013)
\end{abstract}

More than 30 million individuals in the United States have osteoarthritis (OA). ${ }^{1}$ However, there are no diseasemodifying OA drugs (DMOADs) available. Existing drugs for the treatment of OA primarily treat the pain associated with a rapidly deteriorating joint. Unfortunately, no amount of analgesics or joint lubricating agents can prevent the cartilage from being destroyed in the development of OA. However, one of the unique characteristics in the development of OA is the extremely long delay (spanning decades) between an initiating event and the onset of the pain, lack of mobility, and reduced quality of life associated with advanced OA. Understanding of the molecular basis underlying this long delay period can provide invaluable information in the effort to develop novel therapeutic targets for the development of DMOAD to prevent joint destruction.

Articular cartilage degeneration is one of the pivotal pathologic processes in the development of OA. Regardless of the complexity of the OA etiology, the pathologic progress of the articular cartilage degeneration is consistently characterized by the increased activity of chondrocytes at the early stages of the cartilage degeneration, followed by the degradation of proteoglycans and type II collagen, and the final appearance of fibrillation and missing cartilage. ${ }^{2-5}$ This consistent pathologic change suggests that there may be

Supported in part by Servier Laboratories (France) (Y.L. and L.X.). Disclosures: None declared. 
multiple initiating pathways toward the common targets that contribute to articular cartilage degeneration. Therefore, the identification of molecular pathways underlying the cartilage degeneration may not only help us understand the disease better but may also provide us with therapeutic targets for the design of novel clinical protocols in the prevention and treatment of OA.

High-temperature requirement A1 (HTRA1) is a serine protease. ${ }^{6,7}$ Substrates of HTRA1 have been identified, including decorin, biglycan, fibromodulin, aggrecans, and fibronectin. These molecules are pericellular components of chondrocytes in articular cartilage. The level of HTRA1 is increased in synovial fluids obtained from OA and rheumatoid arthritis patients. ${ }^{7,8}$ HTRA1 is the most abundant protease in human OA cartilage. ${ }^{9}$ The increased expression of HtrA1 is associated with osteoarthritic joints in the mice. ${ }^{10}$ The elevated expression of the enzyme is associated with the disruption of the pericellular matrix of chondrocytes. ${ }^{11}$ Together, the aforementioned findings indicate that the increase in the expression and activity of HTRA1 may be involved in the pathogenesis of OA. More important, however, more in vivo data are needed to demonstrate a causal relationship between HTRA1 and the development of OA.

Herein, we present evidence to indicate that HTRA1 may be a rate-limiting factor in the progressive process of articular or condylar cartilage degeneration. Genetic approaches were used to remove HtrAl in a spontaneous mutant mouse model of OA. Surgical destabilization of the medial meniscus (DMM) in HtrAl-deficient $\left(\mathrm{HtrAl}^{-1-}\right)$ mice and partial discectomy (PDE) on temporomandibular joints (TMJs) of $\mathrm{HtrAl}^{-1-}$ mice was performed. Knee joints and TMJs were collected at different ages of mice and analyzed for the pathologic changes of articular or condylar cartilage degeneration.

\section{Materials and Methods}

\section{Generation and Characterization of $\mathrm{HtrA1}^{-/-}$Mice}

The more detailed information of the generation of $\mathrm{HtrAl}^{-/-}$mice has been described in a previous publication. $^{12}$ In this investigation, RT-PCRs were performed to verify whether HtrAl was completely knocked out. Total RNAs were isolated from brain, heart, and muscles for the synthesis of cDNAs. The cDNAs were synthesized with oligo(dT). The PCR primers for the detection of the first exon of HtrAl were used: forward primer, 5'-AGGTTGAGCTGAAGAATGGAGC-3'; and reverse primer, 5'-AATTCTCCAGGTCTCAGCTCTG-3'.

\section{Morphologic Characterization of Articular and Condylar Cartilages in $\mathrm{HtrA1}^{-/-}$Mice}

Knee joints $(n=4)$ and TMJs $(n=4)$ were collected from $\mathrm{HtrAl}^{-/-}$and their wild-type littermates at the age of 15 months. All joints were fixed and processed for paraffin embedding. Serial sections ( $6 \mu \mathrm{m}$ thick) were cut from the anterior to the posterior side of each joint. Every tenth section was collected for Safranin O/Fast Green staining.

\section{Examination of Bone Density of $\mathrm{HtrA1}^{-/-}$Mice}

A radiographic analysis was performed on two $\mathrm{HtrAl}^{-1-}$ mice and two wild-type littermates at the age of 15 months. The mice were exposed to the imaging system (Bruker InVivo FX PRO, Billerica, MA) at 35 peak $\mathrm{kV}$ X-rays for 30 seconds. The radiographic images were taken to indicate the density of the mice skeletons.

A high-resolution desktop microtomographic imaging system $(\mu \mathrm{CT} 40 ;$ Scanco Medical AG, Brüttisellen, Switzerland) was also used to assess the bone density of the tibial epiphysis. Protocols suggested by the Journal of Bone Mineral Research guidelines were used for image acquisition and analysis. ${ }^{13}$ Morphometric variables were computed from the binarized images using direct, three-dimensional techniques that did not rely on any prior assumptions about the underlying structure. ${ }^{14-16}$ Measurements of the whole cross-section of the tibial epiphysis included total volume $\left(\mathrm{mm}^{3}\right)$, bone volume $\left(\mathrm{mm}^{3}\right)$, bone volume fraction (bone volume/total volume; \%), bone mineral density $\left(\mathrm{mgHA} / \mathrm{cm}^{3}\right)$, and tissue mineral density $\left(\mathrm{mgHA} / \mathrm{cm}^{3}\right)$.

\section{DMM of Mouse Knee Joint}

The experimental procedure was performed after approval from the Harvard Medical School (Boston, MA) Institutional Animal Care and Use Committee. HtrAl ${ }^{-1-}$ mice and their wild-type littermates, at the age of 10 weeks, were anesthetized with ketamine (90 $\mu \mathrm{g} / \mathrm{g}$ body weight) and xylazine $(25 \mu \mathrm{g} / \mathrm{g}$ body weight) intraperitoneally. Right knees were prepared for DMM surgery. Buprenorphine was provided perioperatively at $0.09 \mu \mathrm{g} / \mathrm{kg}$. The intercondylar region was exposed, and the medial meniscotibial ligament was divided into sections. Buprenorphine hydrochloride (Par Pharmaceutical, Chestnut Ridge, NY) was also provided subcutaneously at $15 \mathrm{ng} / \mathrm{g}$ body weight twice per day for 2 days post-surgically. Knee joints were harvested from $H \operatorname{trAl} 1^{-1-}$ mice $(n=8)$ and wild-type littermates $(n=8)$ at 8 and 16 weeks after the surgery.

\section{A PDE of Disk in Mouse TMJ}

The experimental procedure was performed after approval from the Harvard Medical School Institutional Animal Care and Use Committee. The detailed surgical procedure has been described previously. ${ }^{4}$ Briefly, $\mathrm{HtrAl}^{-/-}$mice and their wildtype littermates, at the age of 10 weeks, were used for the surgery. Each mouse was anesthetized with ketamine and xylazine intraperitoneally. The left TMJ was open, and the lateral part of the disk was removed. Buprenorphine hydrochloride (analgesic) was provided for 2 days post-surgically. 
Immediately after the surgery, powder food was supplied to the mice for a week and then replaced with regular food. The joints were harvested from $H \operatorname{trAl} 1^{-1-}$ mice $(n=8)$ and wildtype littermates $(n=8)$ at 4 and 12 weeks after the operation.

\section{Generation of the Compound Mutant, $\mathrm{HtrA1}^{-/-}$; Col11a1 ${ }^{+/-}$, Mice}

Collagen type XI-haploinsufficient $\left(\mathrm{Colllal}^{+/-}\right)$mice are a spontaneous mouse model of OA. It takes approximately 12 to 15 months for Colllal ${ }^{+/-}$mice to develop a typical OA knee joint. ${ }^{3}$ In this experiment, $\mathrm{HtrAl}^{-/}$mice were crossed with Colllal $^{+/-}$mice. The double-heterozygous knockout, $\mathrm{HtrAl}^{+/-} ; \mathrm{Colllal}^{+/-}$, mice were identified by PCR. The PCR procedure for the identification of Coll lal $^{+/-}$mice has been described previously. ${ }^{3}$ The PCR procedure for the identification of $\mathrm{HtrAl}^{+/-}$mice was described above in the section of the generation and characterization of $\mathrm{HtrAl}^{-1-}$ mice. The double-heterozygous knockout male and female mice were crossed to generate the compound mutant, $\mathrm{HtrAl}^{-/-}$;Coll $\mathrm{IaI}^{+/-}$, mice. Littermates, Coll $\mathrm{al}^{+/-}$mice, and wild-type mice were used as controls. The mice were euthanized at the ages of 3, 9, and 15 months for the collection of knee joints and TMJs.

\section{Histologic and Immunohistostaining Analysis of the Articular and Condylar Cartilages of Mouse Joints}

For histology, the same experimental procedure described above in the section of the morphologic characterization of articular and condylar cartilages in $\mathrm{HtrAl}^{-1-}$ mice was used. Eight joints were collected from each experimental group. For the evaluation of the morphology of mouse articular and condylar cartilages, a scoring system, recommended by the Osteoarthritis Research Society International, ${ }^{17}$ was modified. On the basis of the morphologic appearance during the progressive process of the cartilage degeneration, the following ranking was used: chondrocyte cluster and/or Safranin O staining increase, 1; loss of Safranin O staining, 2; fibrillation above the tidemark, 3 ; fibrillation reaching to the tidemark, 4 ; cartilage missing $<25 \%$ of the cartilage surface, 5 ; cartilage missing $<50 \%$ of the cartilage surface, 6 ; cartilage missing $<75 \%$ of the cartilage surface, 7 ; and cartilage missing $>75 \%$ of the cartilage surface, 8 . The morphologic conditions of meniscus, subchondral bone, and synovial membrane were also analyzed to assess the overall condition of the joint.

For immunohistostaining, four randomly selected knee joints from Coll lal ${ }^{+-}$mice and their littermates at the age of 9 months were used. Eight sections from each joint were collected for immunohistostaining. The sections were incubated with a polyclonal antibody against HtrA1 (1:200 dilution; Abcam Inc., Cambridge, MA; catalog number ab38611), a polyclonal antibody against discoidin domain receptor 2 (Ddr2; 1:300 dilution; Abcam Inc.; catalog number ab203219), or a polyclonal antibody against matrix metalloproteinase-13 (Mmp-13) (1:300 dilution; Abcam Inc.; catalog number ab84594) at $4{ }^{\circ} \mathrm{C}$, overnight. After that, the samples were incubated with a biotinylated secondary antibody (goat anti-rabbit IgG-B). Sections were treated with a mixture of avidin and biotinylated horseradish peroxidase (VECTASTAIN ABC Kit; Vector Laboratories, Burlingame, CA; catalog number PK-4000). Then, NovaRED peroxidase substrate (Vector Laboratories; cata$\log$ number SK-4800) was used for color detection. Sections were counterstained with $0.2 \%$ Fast Green solution.

\section{Measurement of the Level of Ddr2 and Mmp13 mRNA in Articular Cartilages by Real-Time PCR}

Knee joints of $\mathrm{HtrAl}^{-/-}$;Coll lal ${ }^{+/-}$mice $(n=3)$, Coll1a1 ${ }^{+/-}$mice $(n=3)$, and wild-type littermates $(n=$ 3 ), at the age of 9 months, were obtained. Articular cartilages were sliced off from the tibia and femoral condyles and then were pooled together for the isolation of total RNAs by using an Rneasy Micro Kit (Qiagen, Germantown, MD; catalog number 74004). The cDNA was synthesized with oligo(dT) primer. PCR primers were as follows: $D d r 2$, $5^{\prime}$-CTGTCGGATGAGCAGGTTAT-3' (forward) and $5^{\prime}$ CTCGGCTCCTTGCTGAAGAA-3' (reverse); Mmp 13, $5^{\prime}$ GTGTGGAGTTATGATGATGT-3' (forward) and $5^{\prime}$ TGCGATTACTCCAGATACTG-3' (reverse); and Gapdh, $5^{\prime}$-ACTGAGGACCAGGTTGTC-3' (forward) and $5^{\prime}$ TGCTGTAGCCGTATTCATTG- $3^{\prime}$ (reverse). The concentrations of the primers used in PCRs were as follows: $D d r 2$, $600 \mathrm{nmol} / \mathrm{L} ;$ Mmp-13, $600 \mathrm{nmol} / \mathrm{L}$; and Gapdh, $200 \mathrm{nmol} / \mathrm{L}$. PCR was performed using the StepOnePlus (Applied Biosystems, Beverly, MA). Each cDNA sample was analyzed in triplicate. The experiment was performed twice.

\section{Western Blot Analysis for Examination of Collagen Type VI in Mouse Articular Cartilages}

Knee joints of Coll lal ${ }^{+/-}$mice $(n=3)$ and $\mathrm{HtrAl}^{-1-}$; Coll lal ${ }^{+/-}$mice $(n=3)$, at 9 months of age, were collected. Articular cartilages were collected from the surface of tibia and femoral condyles and were then pooled and transferred into a tube containing $90 \mu \mathrm{L}$ of RIPA Lysis \& Extraction Buffer (G-Biosciences, St. Louis, MO; catalog number 786-489) and $1 \times$ protease and phosphatase inhibitors (ThermoFisherScientific, Waltham, MA; catalog number 78443). The tissues were homogenized and centrifuged. The supernatant was collected for the analysis. Equal amounts of total proteins were loaded into an acrylamide/bisacrylamide gel and transferred to a polyvinylidene difluoride membrane. The membrane was incubated with a rabbit polyclonal antibody against collagen type VI (Abcam Inc.; catalog number ab199720) overnight. The membrane was then incubated with horseradish peroxidase-conjugated secondary antibodies. Western blot analyses were developed by enhanced chemiluminescence (PerkinElmer, Waltham, MA) and detected by $\mathrm{X}$-ray films. 

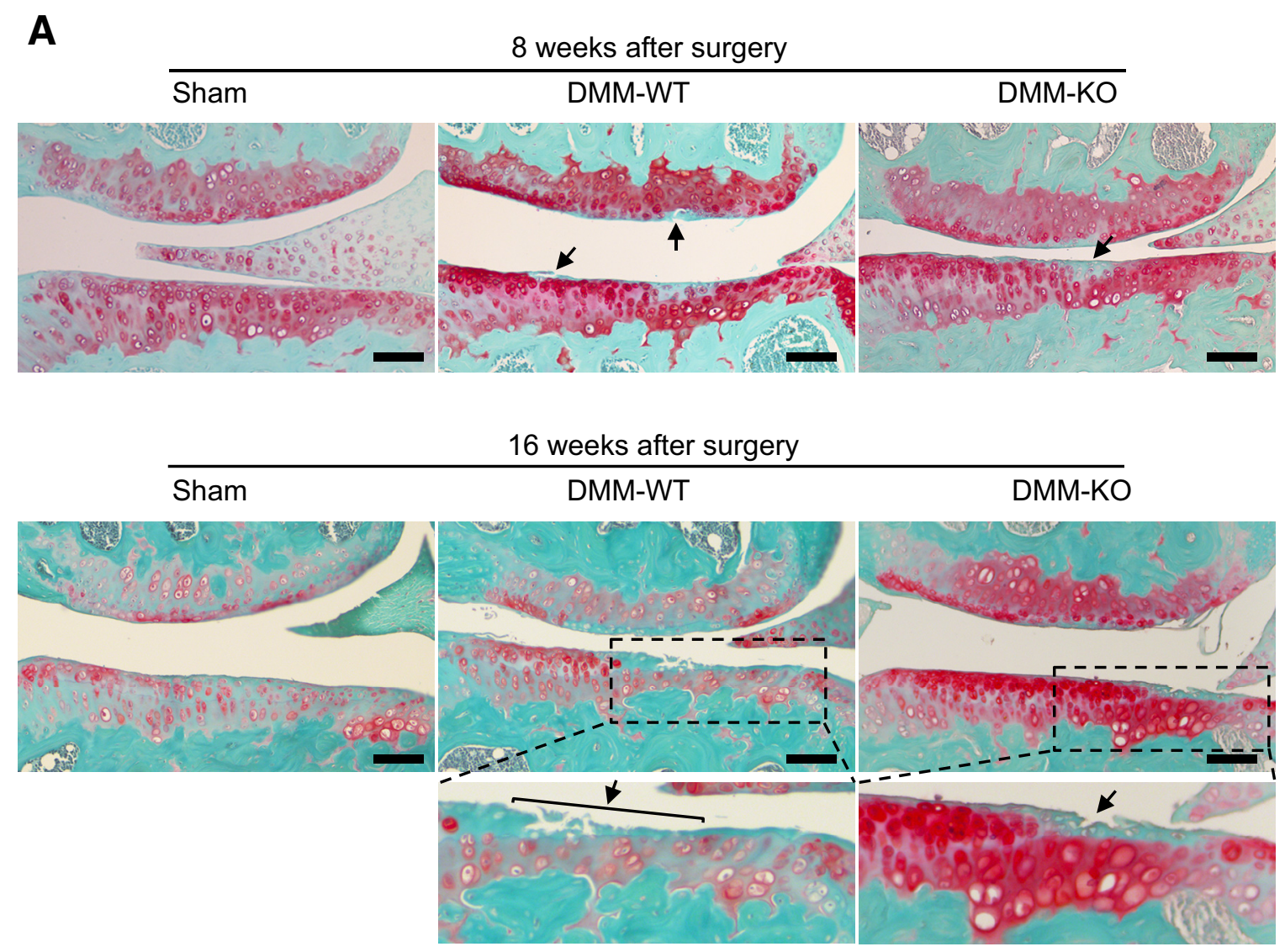

B

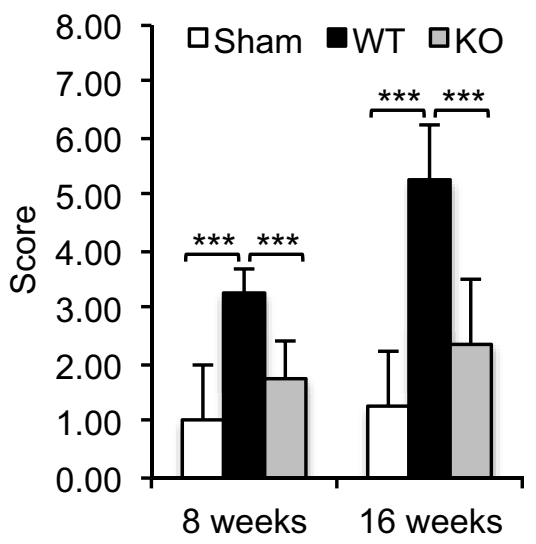

Figure 1 Morphology and evaluation of knee joints in $\mathrm{HtrA1}^{-/-}$mice after destabilization of the medial meniscus (DMM). A: Morphology of articular cartilages of mouse knee joints. There are no overt morphologic changes in the articular cartilage of knee joints in the sham mice at 8 and 16 weeks. However, fibrillation is seen in the articular cartilage of the wild-type (WT) littermates at 8 weeks after DMM (arrows, middle panel). In $\mathrm{HtrA1}^{-/-}$mice, only the localized absence of the proteoglycans is observed (arrow, right panels). At 16 weeks after the surgery, the loss of the articular cartilage is evident in wildtype mice (arrow and bracket show the area of cartilage missing in the left enlargement). In $\mathrm{HrA1}^{-/-}$mice, only the fibrillation is seen (arrow, right enlargement). B: Evaluation of the articular cartilage of knee joints. The histogram shows that the severity of the cartilage damage is significantly different between $\mathrm{HtrA}^{-/-}$mice and their littermates at both 8 and 16 weeks after DMM. ${ }^{* * * P}<0.001$. Scale bar $=100 \mu \mathrm{m}$ (A). K0, knockout.

\section{Statistical Analysis}

In the histologic examination, 10 to 12 paraffin sections were scored. The section with the worst score was used to represent that joint. An average score was calculated from the 10 to 12 scores for each group. $t$-Tests were used in this study. To determine sample size, a pilot study was performed on the effect of the HtrAl deficiency on mice by DMM. The result indicated that a sample size of a minimum of 5 was required to achieve the $95 \%$ CI with at least $50 \%$ reduction of the score in the treatment group. For real-time quantitative PCR analysis also, the $t$-test was used.

\section{Results}

Characterization of $\mathrm{HtrA1}^{-/-}$Mice

A 148-bp DNA PCR product of the first exon of $\mathrm{HtrAl}$ was generated from cDNA of brain, heart, and muscle of wildtype littermates. However, the PCR product was not 


\section{Sham}

PDE-WT

PDE-KO
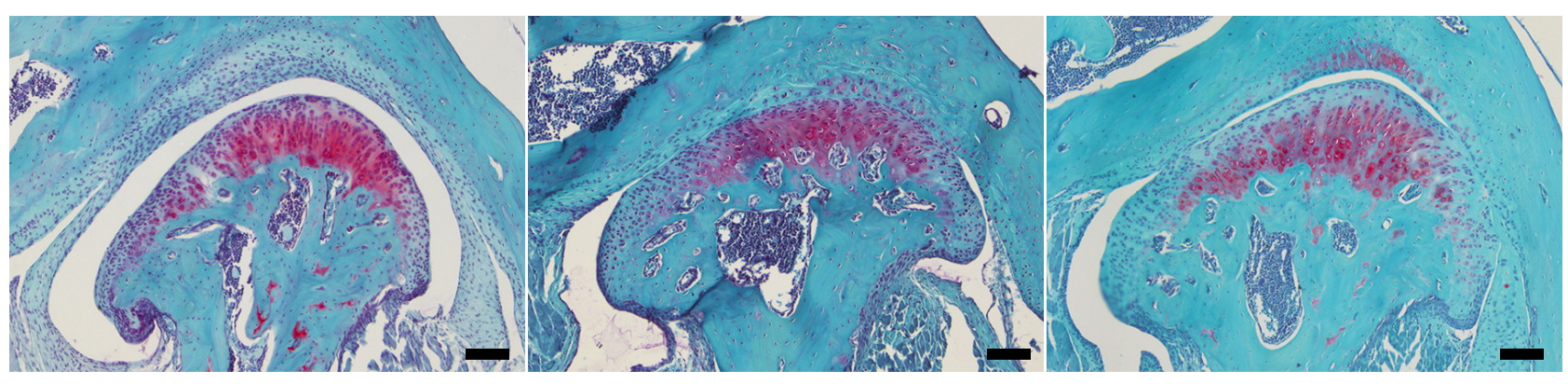

12 weeks after surgery

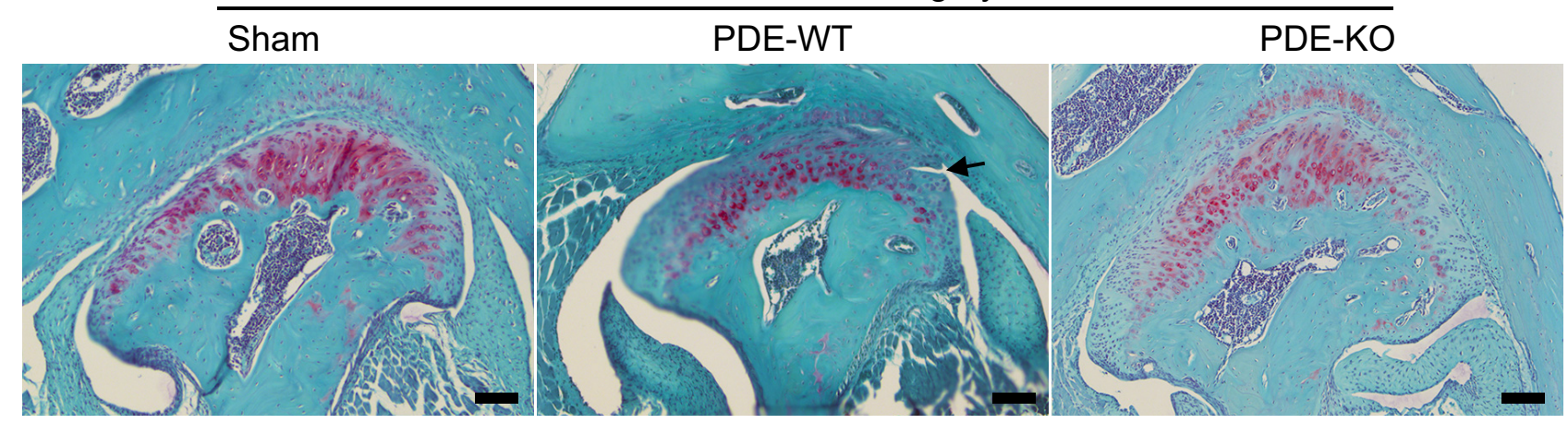

B

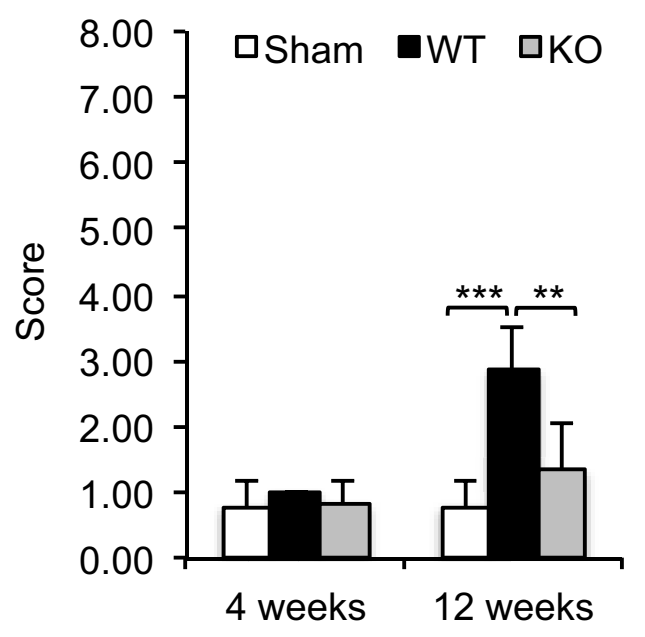

Figure 2 Morphology and evaluation of temporomandibular joints (TMJs) in $\mathrm{HtrA1}^{-/-}$mice after partial discectomy (PDE). A: Morphology of the condylar cartilage of TMJs. At 4 weeks after PDE, the morphologic changes are similar in both wild-type (WT) mice and $H \operatorname{trA1}{ }^{-/-}$mice, characterized by the overproduction of proteoglycans in the condylar cartilage and in the fossa of temporal bones of TMJs. At 12 weeks after $\mathrm{PDE}$, the fibrillation appears in the wild-type mice (arrow) but is not seen in $\mathrm{HtrA1}{ }^{-1-}$ mice. B: Evaluation of the condylar cartilage of TMJs in mice. There are no significant differences in the scores between the wild-type littermates and $\mathrm{HtrA1}^{-/-}$mice at 4 weeks after PDE. However, the score is significantly higher in the wild-type mice, compared with that in $H$ trA1 ${ }^{-1-}$ mice at 12 weeks after PDE. There is significant difference between the sham and PDE in wild-type mice at 12 weeks after operation. ${ }^{*} P<0.01,{ }^{* * * P}<0.001$. Scale bar $=50 \mu \mathrm{m}$ (A). K0, knockout.

detected in cDNA of brain, heart, and muscle from $\mathrm{HtrAl}^{-1-}$ mice (Supplemental Figure S1A), indicating that there was no expression of HtrAl mRNA in $H t r A I^{-/-}$mice.

The morphology of the articular cartilage of knee joints and the condylar cartilage of TMJ from $\mathrm{HtrAl}^{-1-}$ mice, at the age of 15 months, was examined by histology. No abnormal morphologic changes were observed in the cartilages of $\mathrm{HtrAl}^{-1-}$ mice at 15 months of age (Supplemental Figure S1B), indicating that the deletion of HtrAl did not cause any overt morphologic change in the cartilages of knee joints and TMJs in the mice.

The density of bone in $\mathrm{HtrAl}^{-/-}$mice, at 15 months of age, was examined by $\mathrm{X}$-ray. No significant differences were observed in the bone density between $\mathrm{HtrAl}^{-1-}$ mice and their wild-type littermates (Supplemental Figure S1C). The density of the tibial epiphysis was examined in $\mathrm{HtrAl}^{-1-}$ mice by micro-computed tomography. Again, no significant differences were observed in the total bone volumes and bone tissue mineral densities in the tibial epiphyses between $\mathrm{HtrAl}^{-1-}$ and wild-type littermates at the age of 15 months (Supplemental Table S1 and Supplemental Figure S1D). This indicated that the removal 
A
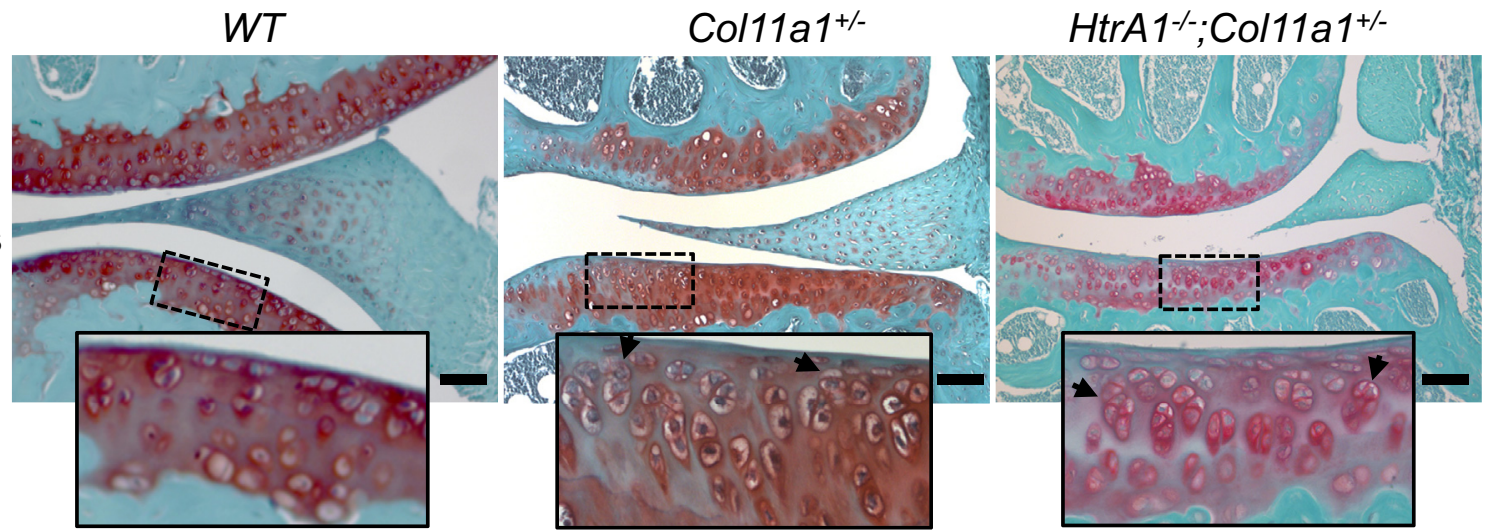

3 months
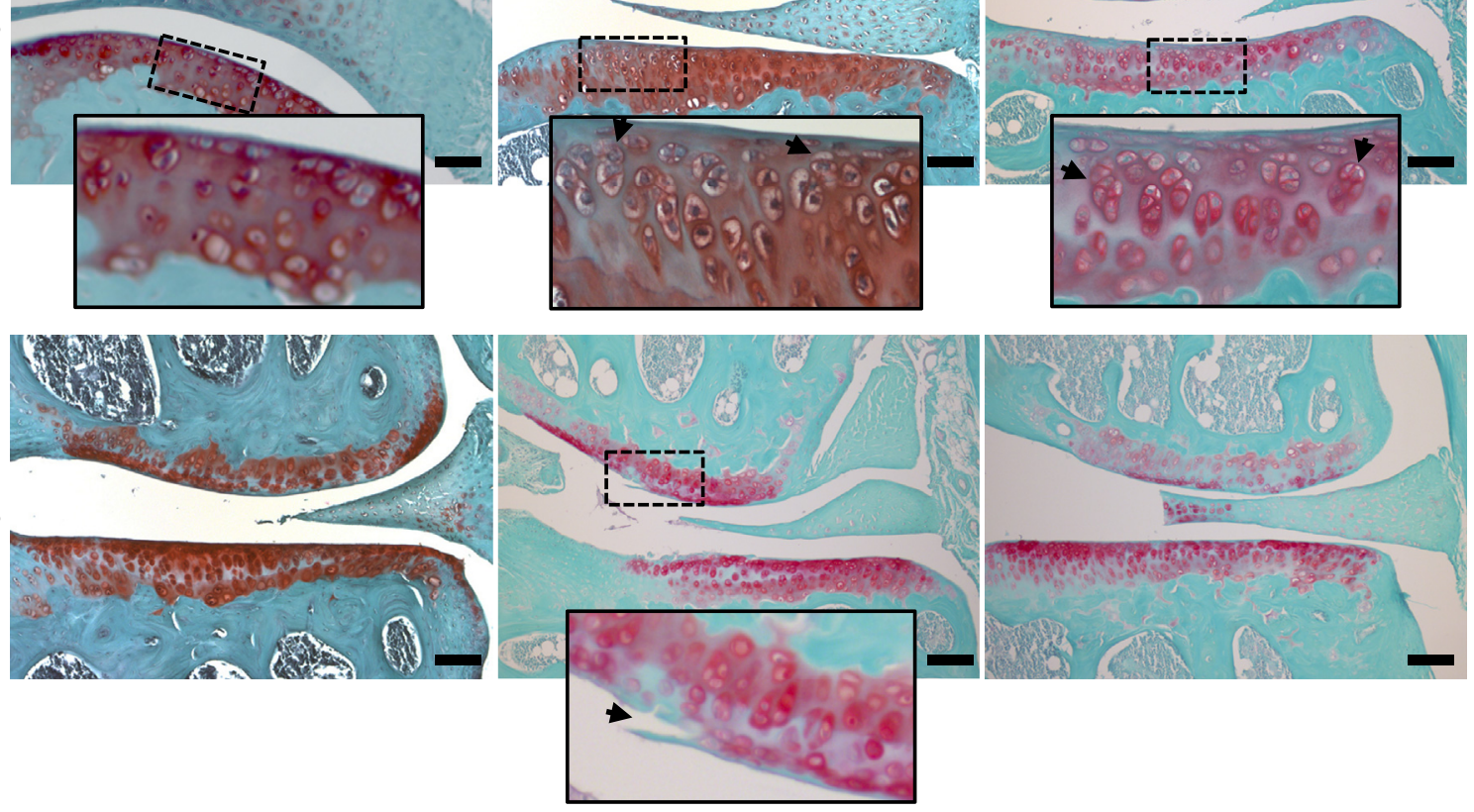

\section{9 months}
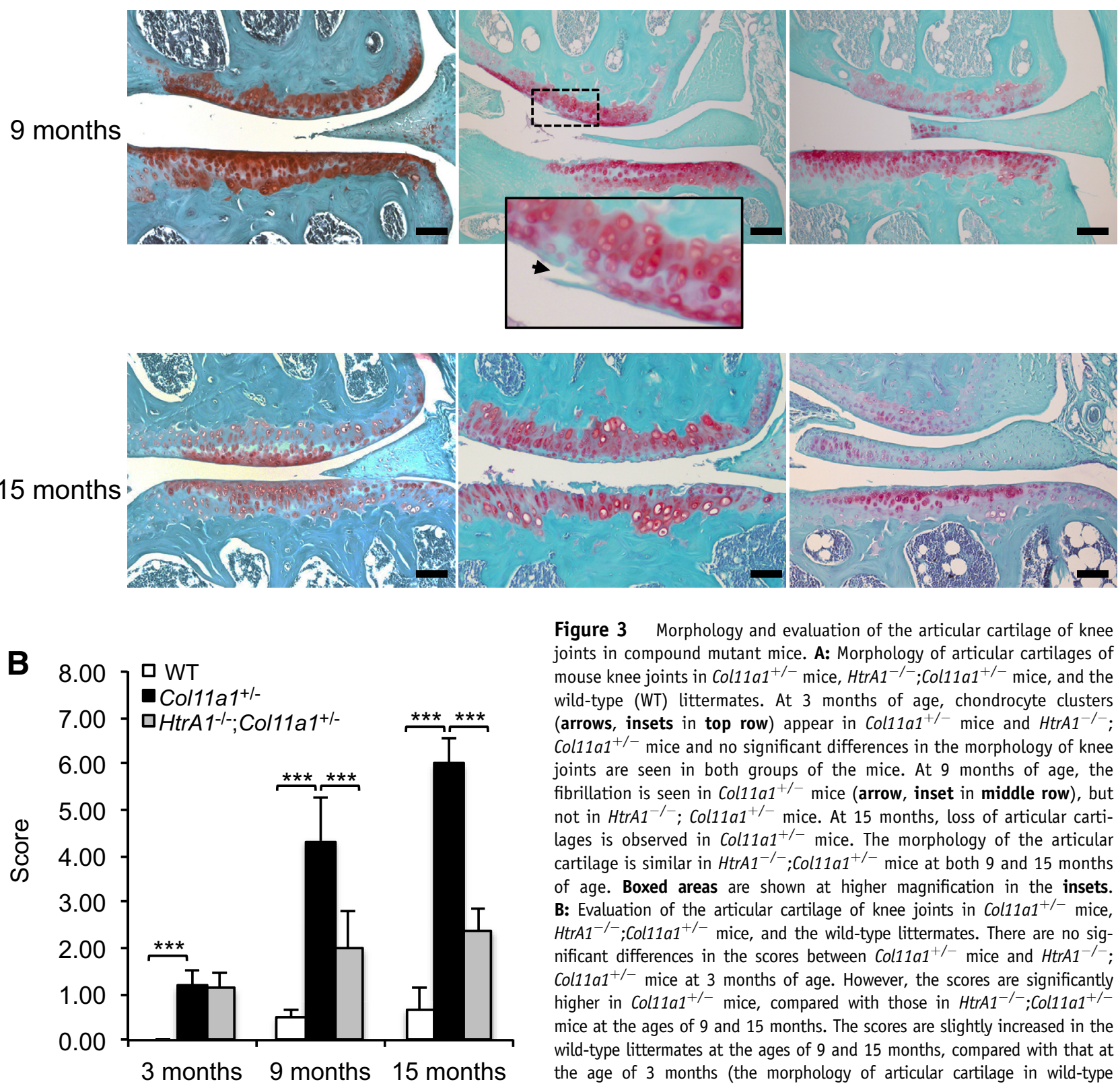

Figure 3 Morphology and evaluation of the articular cartilage of knee joints in compound mutant mice. A: Morphology of articular cartilages of mouse knee joints in Col11a1 $1^{+/-}$mice, $\mathrm{HtrA1}^{-/-} ; \mathrm{Col}_{11 \mathrm{a1} 1^{+/-}}$mice, and the wild-type (WT) littermates. At 3 months of age, chondrocyte clusters (arrows, insets in top row) appear in Col11a1 ${ }^{+/-}$mice and $\mathrm{HtrA1}^{-/-}$; Col11a1 $1^{+/-}$mice and no significant differences in the morphology of knee joints are seen in both groups of the mice. At 9 months of age, the fibrillation is seen in Col11a1 $1^{+/-}$mice (arrow, inset in middle row), but not in $\mathrm{HtrA1}^{-/-}$; Col11a1 ${ }^{+/-}$mice. At 15 months, loss of articular cartilages is observed in Col11a1 ${ }^{+/-}$mice. The morphology of the articular cartilage is similar in $\mathrm{HtrA1}^{-/-}$; Col11a1 ${ }^{+/-}$mice at both 9 and 15 months of age. Boxed areas are shown at higher magnification in the insets. B: Evaluation of the articular cartilage of knee joints in Col11a1 ${ }^{+/-}$mice, $\mathrm{HtrA1}^{-/-} ; \mathrm{Col}_{11 \mathrm{ar}}{ }^{+/-}$mice, and the wild-type littermates. There are no significant differences in the scores between Col11a1 ${ }^{+/-}$mice and $\mathrm{HtrA1}^{-/-}$; Col11a1 ${ }^{+/-}$mice at 3 months of age. However, the scores are significantly higher in Col11a1 ${ }^{+/-}$mice, compared with those in $\mathrm{HtrA1}^{-/-}$; Col11a1 ${ }^{+/-}$ mice at the ages of 9 and 15 months. The scores are slightly increased in the wild-type littermates at the ages of 9 and 15 months, compared with that at the age of 3 months (the morphology of articular cartilage in wild-type littermates was used as normal articular cartilage; score, 0$) .{ }^{* * *} P<0.001$. Scale bar $=100 \mu \mathrm{m}(\mathbf{A})$. 
of HtrAl did not affect the bone density in the epiphysis of adult mice.

\section{Chondroprotective Effect of the Genetic Deletion of HtrA1 on Cartilages in Injurious Mouse Models of OA}

First, significant disparities were observed in the progressive process of articular cartilage degeneration in knee joints between $\mathrm{HtrAl}^{-1-}$ mice and the wild-type littermates after DMM surgery at the age of 10 weeks (Figure 1A). The progressive process of articular cartilage degeneration was significantly delayed in $\mathrm{HtrAl}^{-1-}$ mice after DMM surgery. The severity of the cartilage damage was evaluated by the scoring system. At 8 weeks after DMM surgery, the average scores for $\mathrm{HtrAl}^{-1-}$ mice and wild-type littermates were 1.75 and 3.25, respectively. At 16 weeks after DMM surgery, the average scores were 2.38 for $\mathrm{HtrAl}^{-1-}$ mice and 5.25 for wild-type littermates. The scores were significantly different between two groups at each time point (Figure 1B).

Second, the progression of OA was significantly delayed in $\mathrm{HtrAl}^{-1-}$ mice after PDE surgery. At 12 weeks after the surgery, significantly less damaged condylar cartilages were seen in $\mathrm{HtrAl}^{-1-}$ mice (Figure 2). However, no difference was observed in the morphology of condylar cartilages between $\mathrm{HtrAl}^{-1-}$ mice and their wild-type littermates at 4 weeks after the surgery.

\section{Chondroprotective Effect of the Genetic Removal of HtrA1 on Cartilages in an Aging-Related Mouse Model of $O A$}

Coll lal $^{+/-}$mice developed normally, with the exception of early-onset OA. At 3 months of age, chondrocyte clusters appeared in the articular cartilage of Coll1al ${ }^{+/-}$mice (Figure 3A). At 9 months of age, fibrillation and localized proteoglycan degradation were seen in the articular cartilage of Colllal ${ }^{+-}$mice. At 15 months, Colllal ${ }^{+/}$mice revealed several features of a typical OA knee joint, including loss of articular cartilage and misshapen menisci. However, although chondrocyte clusters appeared in the articular cartilage of knee joints in $\mathrm{HtrAl}^{-1-}$;Coll $\mathrm{CaI}^{+/-}$mice at 3 months of age, there was no fibrillation or loss of articular cartilage observed in $\mathrm{HtrAl}^{-1-}$; Coll $1 \mathrm{al}^{+/-}$mice at 9 and 15 months of age (Figure 3A). The condition of the articular cartilage was also evaluated by the scoring system. Articular cartilage of knee joints in wild-type littermates at 3 months of age was used as a reference point for normal articular cartilage, with a score of 0 . The scores in each group are indicated in Figure 3B. The scores increased slightly with age in $\mathrm{HtrAl}^{-1-}$;Coll lal ${ }^{+/-}$mice, but were not as dramatically increased as they were in Coll $\mathrm{al}^{+/-}$mice. Also, there was no significant increase in scores as $\mathrm{HtrAl}^{-/-} ; \mathrm{Colllal}^{+/-}$ mice aged from 9 to 15 months of age.

TMJ was also characterized in $\mathrm{HtrAl}^{-/-} ; \mathrm{Colllal}^{+/-}$mice (Figure 4A). A slight increase in the production of proteoglycans was seen in both Colllal $1^{+/-}$and $\mathrm{HtrAl}^{-/-}$;
Coll lal $^{+/-}$mice at the age of 3 months. There was no significant difference between these two groups of mice at the age of 3 months. However, fibrillation and loss of condylar cartilage were seen in $\mathrm{Coll} \mathrm{lal}^{+/-}$mice, but not in $\mathrm{HtrAl}^{-1-}$; Coll lal $^{+/-}$mice at the ages of 9 and 15 months. Scores of the condylar cartilages in $\mathrm{HtrAl}^{-1-}$; Colllal ${ }^{+/-}$mice were significantly lower, compared with that in $\mathrm{Colllal}^{+/-}$mice, at the ages of 9 and 15 months (Figure 4B).

Inhibition of Expression of Ddr2 and Mmp-13 and the Protection of Collagen Type VI Degradation in the Articular Cartilage of Knee Joints in Mice by the Deletion of HtrA1

First, immunohistostaining of HtrA1, Ddr2, and Mmp-13 was performed on the articular cartilage of $\mathrm{HtrAl}^{-1-}$; Coll lal ${ }^{+/-}$ mice and their corresponding controls at 9 months of age. The protein expression of these three genes was not detected in the articular cartilage of knee joints in wild-type littermates (Figure 5A). However, the protein expression of these genes was increased in the articular cartilage of Coll1al $1^{+-}$mice. This is consistent with the previous observations. ${ }^{11,18}$ In the articular cartilage of $\mathrm{HtrAl}^{-/-}$; Coll $\mathrm{al}^{+/-}$mice, there was no protein expression of HtrA1. This is also consistent with the result, which indicates that $H t r A l$ is knocked out in $\mathrm{HtrAl}^{-1-}$ mice described above. The protein expressions of Ddr2 and Mmp-13 were also hardly detected in the articular cartilage of $\mathrm{HtrAl}^{-1-} ;$ Coll lal $^{+/-}$mice.

Second, real-time quantitative PCR was performed to measure the levels of $D d r 2$ and Mmpl3 mRNA. There were no increases in the levels of $D d r 2$ and Mmpl3 mRNA in the articular cartilages of knee joints in $\mathrm{HtrAl}^{-1-} ; \mathrm{Colllal}^{+-}$ mice, compared with that in wild-type littermates, at the age of 9 months (Figure 5B). This is in line with the result from the immunohistostaining above.

Third, the protein level of collagen type VI was examined in the articular cartilage of knee joints by Western blot analysis. Collagen type VI is present exclusively in the pericellular matrix of chondrocytes in cartilage. ${ }^{19}$ Thus, degradation/disappearance of collagen type VI is an indication of the pericellular matrix destruction. In our experiment, the protein level of collagen type VI was significantly higher in the articular cartilage of $\mathrm{HtrAl}^{-1-}$;Coll1al ${ }^{+-}$mice, compared with that in Coll lal $^{+--}$mice at the age of 9 months (Figure 5C).

\section{Discussion}

Protective Effect of the Genetic Deletion of HtrA1 on Articular and Condylar Cartilage Degeneration during the Development of OA

An independent research group reported that the genetic inactivation of HtrAl enhanced trabecular bone mass in mice. ${ }^{20}$ Thus, experiments were performed to examine whether the genetic removal of HtrAl in our investigation resulted in increases in bone formation. The results showed 
A

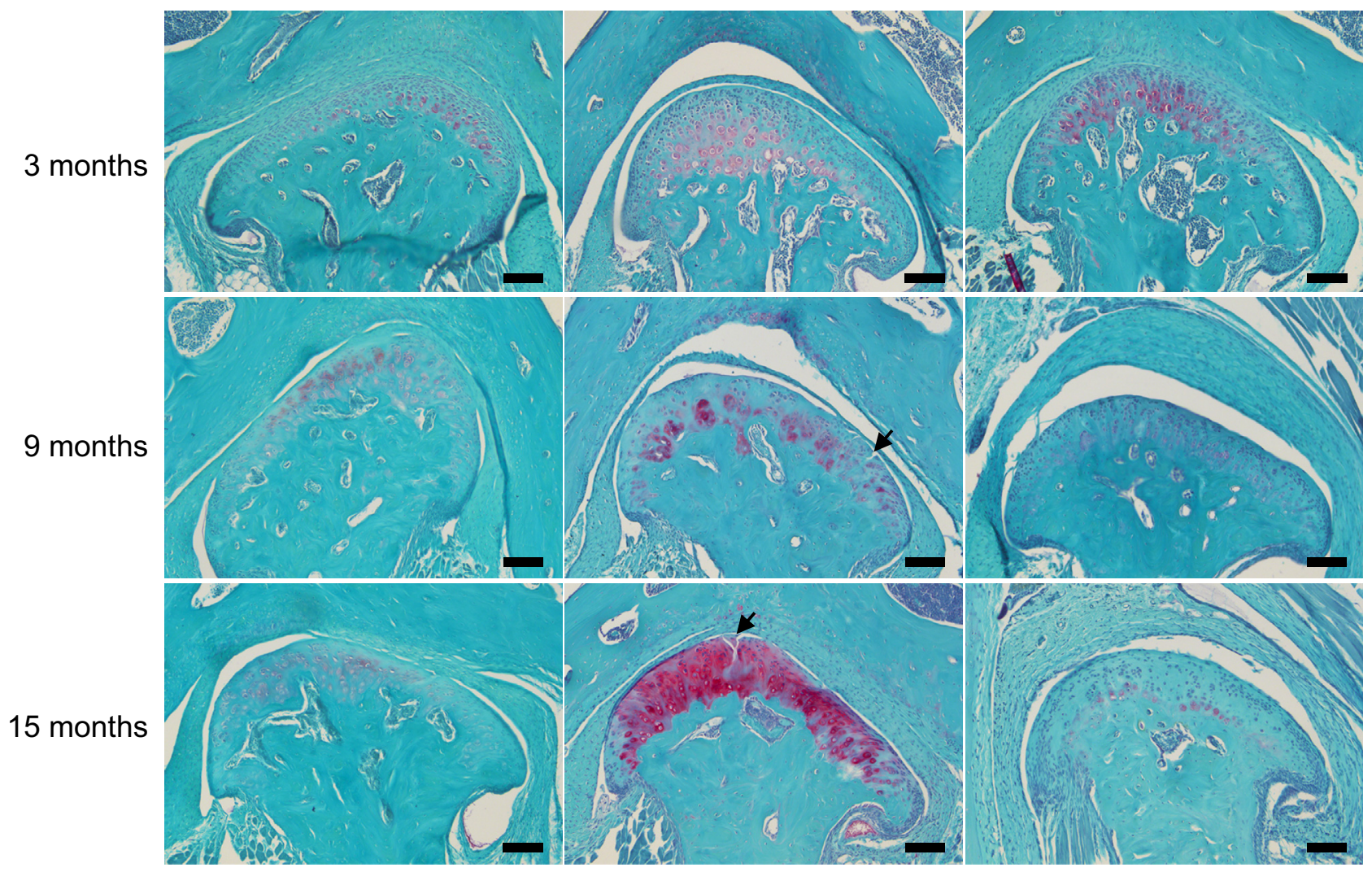

B

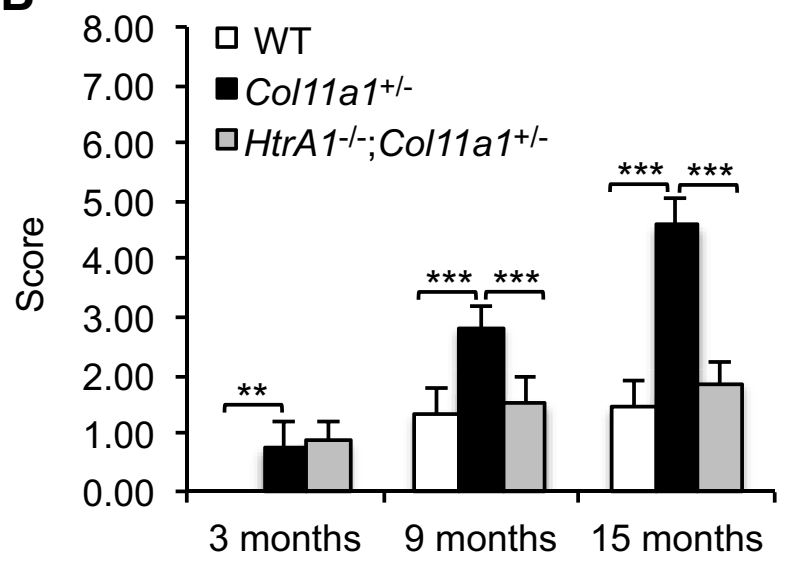

Figure 4 Morphology and evaluation of the condylar cartilage of temporomandibular joints (TMJs) in compound mutant mice. A: Morphology of condylar cartilages of mouse TMJs in Col11a1 ${ }^{+/-}$mice, $\mathrm{HtrA1}^{-/-}$; $\mathrm{Col}_{11 \mathrm{a1} 1^{+/-}}$mice, and the wild-type (WT) littermates. The pathologic changes in the condylar cartilage are similar to those seen in the articular cartilage of Col11a1 ${ }^{+/-}$mice as the mice aged: the overproduction of proteoglycans at 3 months of age, the appearance of fibrillation at 9 months of age (arrow), and the loss of the cartilage (the cartilage falls off the surface of the joint; arrow) at 15 months of age. However, in $\mathrm{HtrA1}^{-/-}$; Col1 $1 a 1^{+/-}$mice, the structure of the condylar cartilage was intact, with the exception of the degradation of proteoglycans, even in the mice at the age of 15 months. B: Evaluation of the condylar cartilage of TMJ Col11a1 ${ }^{+/-}$mice, $\mathrm{HtrA1}^{-/-}$; Col1 $1 \mathrm{a}^{+/-}$mice, and the wild-type littermates. There is no significant difference in the scores between Col11a1 $1^{+/-}$and $\mathrm{HtrA1}^{-/-}$; Col11a1 ${ }^{+/-}$mice at 3 months. However, there is a significant difference between wild-type and Col11a1 $1^{+/-}$or $\mathrm{HtrA1}^{-/-}$; Col11a1 ${ }^{+/-}$mice. The scores are significantly different between Col11a1 ${ }^{+/-}$mice and $\mathrm{HtrA1}^{-/-} ; \mathrm{Col} 11 \mathrm{a1} 1^{+/-}$mice at the ages of 9 and 15 months. The scores are similar between $\mathrm{HtrA1}^{-/-}$;Col11a1 ${ }^{+/-}$mice and their wildtype littermates at the ages of 9 and 15 months. ${ }^{* *} P<0.01,{ }^{* * *} P<0.001$. Scale bar $=50 \mu \mathrm{m}(\mathbf{A})$. that there was no significant difference in the increase of bone density of $\mathrm{HtrAl}^{-1-}$ mice at the age of 15 months. Data from the micro-computed tomographic analysis also indicated that there were no significant differences in total bone volumes and bone tissue mineral densities of the tibial epiphyses between $\mathrm{HtrAl}^{-1-}$ mice and their wild-type littermates at the age of 15 months. The histologic analyses did not find abnormal morphology of articular and condylar cartilages in knee joints and TMJs of $\mathrm{HtrAl}^{-1-}$ mice at the age of 15 months. Because there are several other HtrA family members in mice, they may be able to compensate for the loss of HtrAl during development. On the basis of the result from the characterization of the $\mathrm{HtrAl}^{-1-}$ mice, this mouse strain may be an excellent animal model to investigate whether the deletion of HtrAl has chondroprotective effects.

Two mouse models of OA were used: one spontaneous mutant model $\left(\right.$ Colllal $^{+/-}$mice) and post-traumatic 
A WT Col11a1+/ HtrA1/-;Col11a1+/

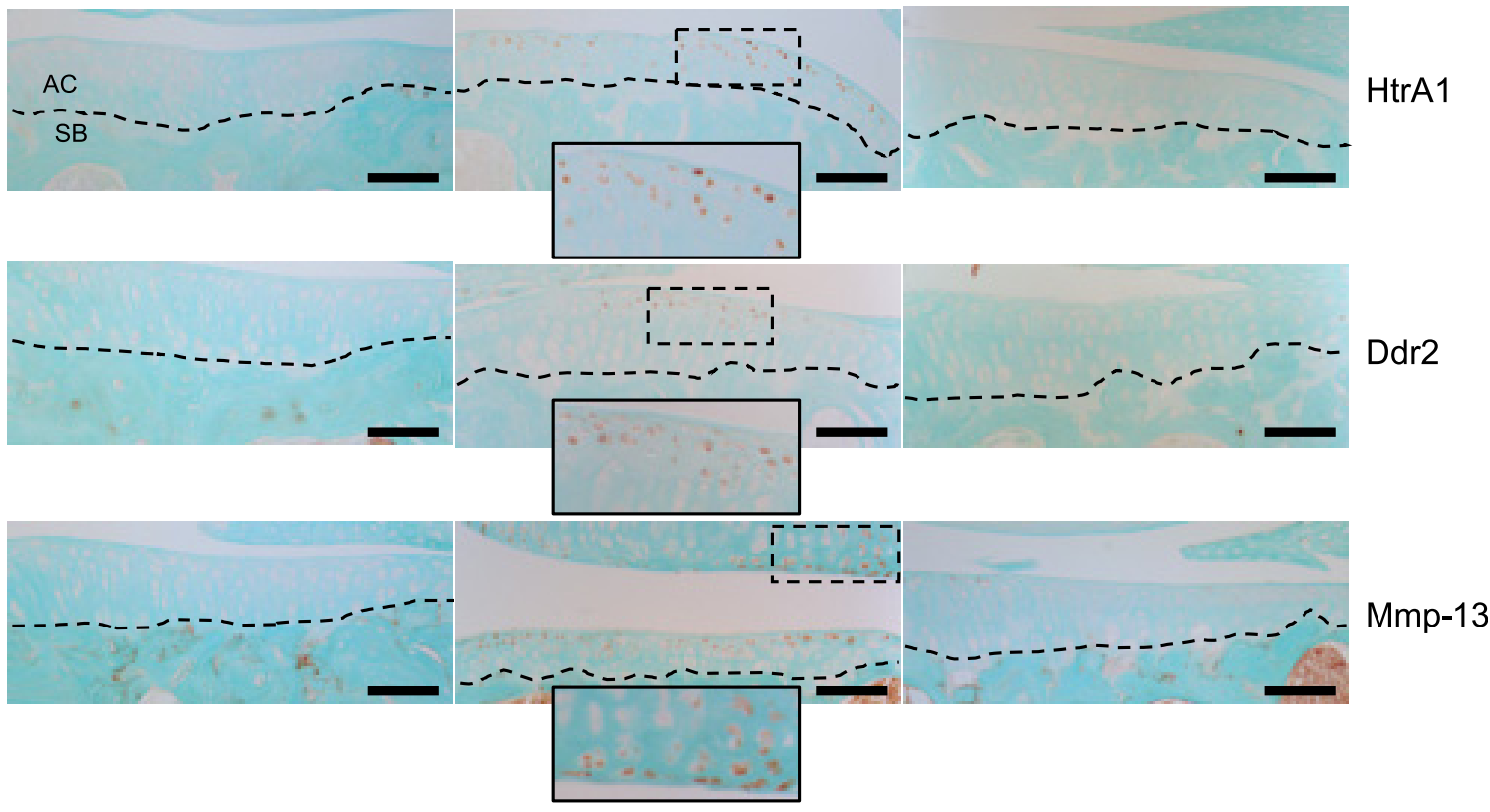

B

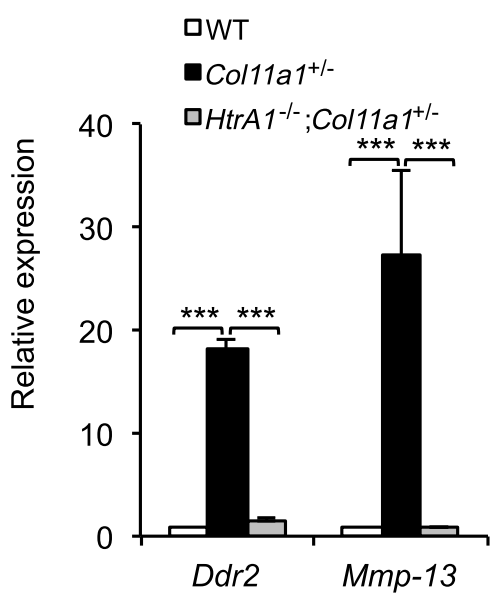

C
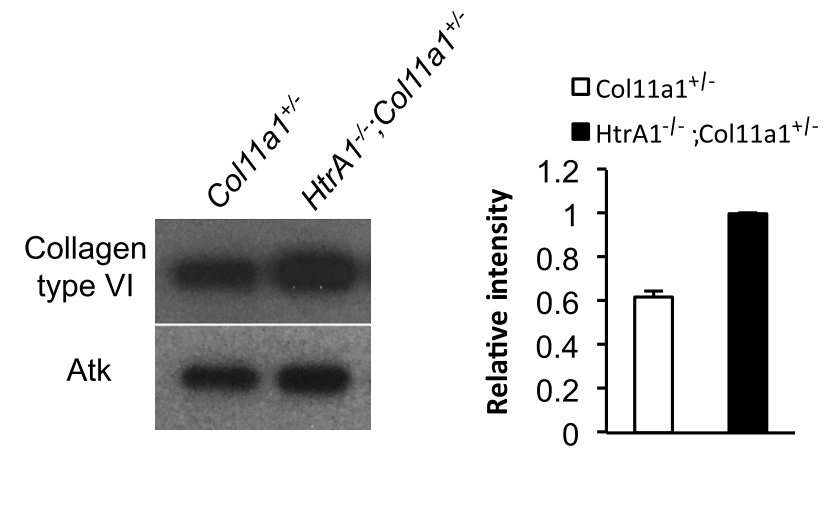

Figure 5 Immunohistostaining and relative expression levels of discoidin domain receptor 2 (Ddr2) and matrix metalloproteinase-13 (Mmp-13) and Western blot analysis of collagen type VI in the articular cartilage. A: Immunohistostaining of HtrA1, Ddr2, and Mmp-13 in the articular cartilage of mice at 9 months of age. The protein expression levels of HtrA1, Ddr2, and Mmp-13 were increased in Col11a1 ${ }^{+/-}$mice (brown-staining cells). But the protein expression of all three genes is not detected in the articular cartilage in $\mathrm{HtrA1}^{-/-}$; Col11a1 ${ }^{+/-}$mice and their wild-type (WT) littermates [dashed lines indicate the borders between articular cartilage (AC) and subchondral bone (SB)]. Boxed areas are shown at higher magnification in the insets. B: Relative expression levels of Ddr2 and Mmp-13 in the articular cartilage of mice at 9 months of age. The levels of Ddr2 and Mmp13 mRNAs are significantly increased in the articular

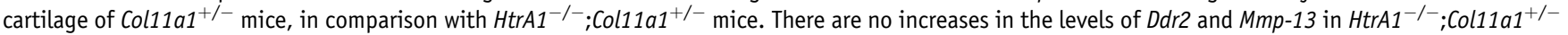
mice, compared with that in their wild-type littermates. C: Western blot analysis of collagen type VI in the articular cartilage of Col11a1 $1^{+/-}$and $H$ trA1 ${ }^{-/-}$; Col11a1 ${ }^{+/-}$mice. The intensity of collagen type VI band is much higher in $\mathrm{HtrA1}^{-/-}$; Col11a1 ${ }^{+/-}$mice. The level of collagen type VI in Col11a1 ${ }^{+/-}$mice is approximately $60 \%$ of the collagen in $\mathrm{HtrA1}^{-/-}$; Col11a1 ${ }^{+/-}$mice. ${ }^{* * *} P<0.001$. Scale bar $=100 \mu \mathrm{m}$ (A).

models (DMM and PDE mice). Knee joints and TMJs were examined in the models. The progressive process of the articular or condylar cartilage degeneration was significantly delayed in mice without HtrA1. This ruled out the possibility that the chondroprotective effect seen with the genetic removal of HtrAl in mice was either a joint- or a modelspecific event. The modified Mankin scores of knee joints were slightly increased from 2.00 to 2.38 and the scores of
TMJ were up from 1.50 to 1.86 from the age of 9 to 15 months in $\mathrm{HtrAl}^{-/-}$; Coll lal ${ }^{+/-}$mice. In the post-traumatic models, the scores of knee joints were increased from 1.75 to 2.38 in $\mathrm{HtrAl}^{-/-}$mice at 8 and 16 weeks, respectively, after DMM. For TMJ, the scores were increased from 0.83 to 1.33 in $\mathrm{HtrAl}^{-1-}$ mice at 4 and 12 weeks, respectively, after PDE. The slight increases in the scores indicate that HtrA1 may be one of the rate-limiting factors in the 


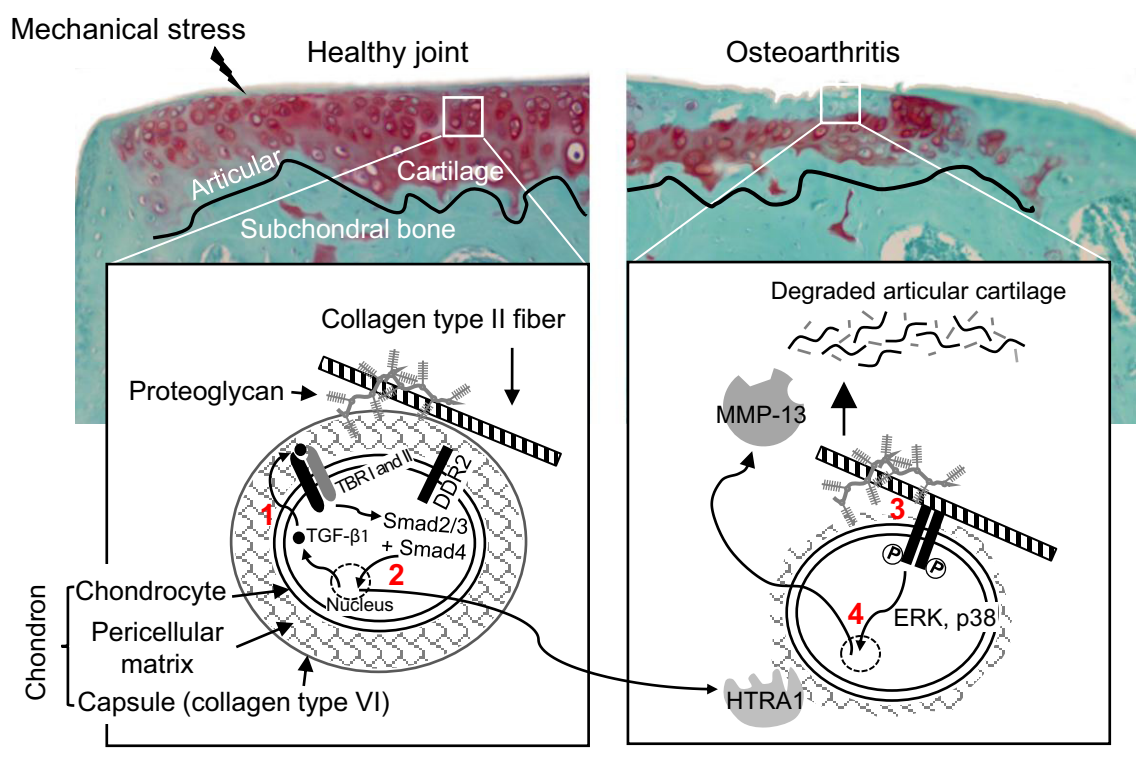

Figure 6 A schematic of a molecular signaling cascade leading to articular cartilage degeneration in the development of osteoarthritis. 1: Excessive mechanical stress induces transforming growth factor (TGF)- $\beta 1$ in articular chondrocytes. 2: TGF$\beta 1 /$ phosphorylated Smad2/3 signaling induces HTRA1. 3: The pericellular matrix of chondrocytes is destructed by HTRA1 to expose discoidin domain receptor 2 (DDR2) to native collagen type II. 4: The interaction of DDR2 with the collagen type II activates DDR2 to induce matrix metalloproteinase-13 (MMP-13) via extracellular signalregulated kinase (ERK) and p38 signaling pathways. In the end, the collagen type II and proteoglycan are degraded by MMP-13. TBR, TGF-beta receptor. acceleration of articular or condylar cartilage degeneration during the development of OA. The genetic deletion of HtrAl did not prevent the formation of chondrocyte clusters or the increase in the production of proteoglycans in articular and condylar cartilages at early stages of cartilage degeneration. This suggests that increases in chondrocyte activities, such as cluster formation and overproduction of proteoglycans, are caused by other factors.

\section{A Possible Role of the Increased HTRA1 in the Acceleration of the Progressive Process of Articular/ Condylar Cartilage Degeneration}

We propose a causal sequence of molecular events that is responsible for articular cartilage degeneration. HTRA1 is one of the key molecules in this molecular sequence (Figure 6).

Excessive mechanical stresses are initial insults to stimulate chondrocytes in cartilages to synthesize and release transforming growth factor- $\beta 1(T G F-\beta 1) .^{21,22}$ The protein expression of Tgf- $\beta 1$ was increased in the articular cartilage of knee joints in Coll lal ${ }^{+/-}$and DMM mice at early stages of articular cartilage degeneration. ${ }^{23}$ It is likely that chondrocytes are not protected properly and can sense an excessive stress under both conditions. In Colllal ${ }^{+/-}$mice, chondrocytes reside in the defective extracellular matrix. Thus, chondrocytes under this condition can feel insulted by normal mechanical stimulation. In DMM mice, the altered geometry of the knee joint can exert excessive stress on the chondrocytes, even those residing in the normal extracellular matrix. Moreover, the conditionally genetic removal of Tgf- $\beta$ receptor II $(T g f b r 2)$ in mature articular cartilage protects knee joints against the development of $\mathrm{OA}$ in mice. ${ }^{24}$ More important, the results from other independent research groups also indicate that TGF- $\beta 1$ may be a detrimental factor in the pathogenesis of $\mathrm{OA}$ in adult joints. ${ }^{25-30}$

TGF- $\beta 1$ induces HTRA 1 in chondrocytes, which leads to the degradation of the pericellular matrix of chondrocytes. The elevated protein expression of phosphorylated Smad2/3 colocalizes with the increased expression of HtrA1 in the articular cartilage of knee joints in Coll lal ${ }^{+/-}$and DMM mice. ${ }^{23}$ TGF- $\beta 1$ induces the expression of HTRA1 in human chondrocytes. ${ }^{31}$ As for the destruction of the pericellular matrix by HtrA1, collagen type VI disappears in chondrocytes expressing HtrAl in Coll $\mathrm{al}^{+/-}$mice. ${ }^{18}$ In articular cartilage, collagen type VI exclusively surrounds chondrocytes to make up the pericellular capsule of chondrocytes. The degradation (disappearance) of collagen type VI is an indication of the integrity of the pericellular matrix. In this study, the removal of HtrAl could protect collagen type VI from being degraded in Coll1a1 ${ }^{+/-}$mice. This indicated that more chondrocytes had an intact pericellular matrix in the articular cartilage of $\mathrm{HtrAl}^{-1-} ; \mathrm{Colllal}^{+/}$ mice than that in the articular cartilage of Coll1a1 ${ }^{+/-}$mice. Western blot analysis was performed to compare collagen type VI in $\mathrm{HtrAl}^{-1-} ; \mathrm{Colllal}^{+/-}$mice with Coll1a1 ${ }^{+-}$ mice. Wild-type mice were not used as one of the controls because the extraction of extracellular matrix components was much different (easier in Coll lal ${ }^{+/-}$mice than in wildtype littermates). Thus, it is difficult to quantitatively compare the amount of collagen type VI in the extracellular matrix of Coll lal ${ }^{+/-}$mice and their wild-type littermates by Western blot analysis.

The disappearance of the pericellular matrix elicits interaction of the collagen type II with $D D R 2$. The pericellular matrix separates chondrocytes from the adjacent interterritorial or territorial matrices containing collagen type II. ${ }^{32,33}$ It is conceivable that one of the consequences of the degradation of the pericellular matrix is to expose chondrocytes to 
collagen type II. This, in turn, results in the interaction of collagen type II with DDR2. The removal of HTRA1 or inhibiting activity of this enzyme could protect the pericellular matrix and prevent DDR2 from being activated. Results from the immunohistostaining experiments showed that the expression of Ddr2 was not increased by the genetic deletion of HtrAl in the articular cartilage of Coll la1 ${ }^{+/-}$ mice. Non-up-regulated expression of Ddr2 reflected the inactive status of Ddr2 because the activation of Ddr2 increases the expression of the receptor itself in chondrocytes. In addition, results from the experiments with the conditionally induced $D d r 2$ in transgenic mice support the pericellular matrix-degrading role of $\mathrm{HtrA} 1$ in the development of OA. ${ }^{18}$ Thus, maintaining the integrity of the pericellular matrix may protect joints against the development of OA. ${ }^{34,35}$

Activation of DDR2 induces expression of MMP-13. The activation of DDR2 by the interaction of chondrocytes with native collagen type II in vitro induces MMP-13. The blockage of extracellular signal-regulated kinase and p38 signaling pathways inhibits the induction of MMP-13 in chondrocytes. ${ }^{36-38}$ The genetically conditional removal of $D d r 2$ in articular cartilage significantly attenuates the progressive process of the cartilage degeneration in mouse models of OA. ${ }^{39,40}$ Also, the activation of DDR2 induces the expression of MMP-13 in chondrocytes. ${ }^{41-44}$

In summary, the excessive mechanical stress can stimulate chondrocytes to synthesize and release TGF- $\beta 1$ in adult joints. This factor then binds to its receptor, inducing signal transduction via phosphorylated SMAD2/3, which results in the induction of HTRA1. HTRA1 degrades the pericellular matrix of the chondrocytes. The destruction of the pericellular matrix exposes chondrocytes to collagen type II. This, in turn, elicits interaction of DDR2 with collagen type II and activates DDR2. The activation of DDR2 induces both expressions of MMP-13 and the receptor itself. MMP13 degrades collagen type II and aggrecans. The end result is OA.

\section{HTRA1 as a Potential Therapeutic Target for Development of DMOADs}

A DMOAD should be able to reverse, stop, or significantly attenuate the developmental process of the disease. There are currently no DMOADs as there are no approved therapeutic targets against which a drug can be developed. Our data demonstrate that HTRA1 may be an ideal target for the development of DMOADs. The genetic inactivation of HtrAl significantly delays the progressive process of articular and condylar cartilage degeneration in mouse models of OA. Thus, biological reagents that can inhibit the enzymatic activity of HTRA1 may be used as DMOADs to treat OA. Because HTRA1 is a serine protease, one of the challenges to pharmaceutical companies is to develop an effective drug that can specifically inhibit HTRA1 with little or no effect on other proteases. A recent study reports an allosteric mechanism of HTRA1 activation and regulation. ${ }^{45}$ This provides possibilities for developing highly selective biological reagents, including small or large molecules and cyclic peptides, to target HTRA1.

\section{Acknowledgments}

P.C., Y.L., and L.X. conceived and designed the study; P.C., T.T., C.L., B.W., M.M., C.O., M.B., Y.L., and L.X. performed experiments and analyzed data; P.C., M.B., Y.L., and L.X. wrote the manuscript; Y.L. and L.X. acquired funding.

\section{Supplemental Data}

Supplemental material for this article can be found at http://doi.org/10.1016/j.ajpath.2019.03.013.

\section{References}

1. Sharma L: Osteoarthritis year in review 2015: clinical. Osteoarthritis Cartilage 2016, 24:36-48

2. Hamerman D: The biology of osteoarthritis. N Engl J Med 1989, 320: $1322-1330$

3. Xu L, Flahiff CM, Waldman BA, Wu D, Olsen BR, Setton LA, Li Y: Osteoarthritis-like changes and decreased mechanical function of articular cartilage in the joints of chondrodysplasia (cho) mice. Arthritis Rheum 2003, 48:2509-2518

4. Xu L, Polur I, Lim C, Servais JM, Dobeck J, Li Y, Olsen BR: Earlyonset osteoarthritis of mouse temporomandibular joint induced by partial discectomy. Osteoarthritis Cartilage 2009, 17:903-908

5. Lotz MK, Otsuki S, Grogan SP, Sah R, Terkeltaub T, D'Lima D: Cartilage cell clusters. Arthritis Rheum 2010, 62:2006-2018

6. Clausen T, Southan C, Ehrmann M: The HtrA family of proteases: implications for protein composition and cell fate. Mol Cell 2002, 10 : 443-455

7. Hu SI, Carozza M, Klein M, Nantermet P, Luk D, Crowl RM: Human $\mathrm{HtrA}$, an evolutionarily conserved serine protease identified as a differentially expressed gene product in osteoarthritic cartilage. J Biol Chem 1998, 273:34406-34412

8. Grau S, Richards PJ, Kerr B, Hughes C, Caterson B, Williams AS, Junker U, Jones SA, Clausen T, Ehrmann M: The role of human HtrA1 in arthritic disease. J Biol Chem 2006, 281:6124-6129

9. Wu J, Liu W, Bemis A, Wang E, Wiu Y, Morris EA, Flannery CR, Yang Z: Comparative proteomic characterization of articular cartilage tissue from normal donors and patients with osteoarthritis. Arthritis Rheum 2007, 56:3675-3684

10. Hou Y, Lin H, Zhu L, Liu Z, Hu F, Shi J, Yang T, Shi X, Zhu M, Godley BF, Wang Q, Li Z, Zhao Y: Lipopolysaccharide increases the incidence of collagen-induced arthritis in mice through induction of protease HTRA-1 expression. Arthritis Rheum 2013, 65:2835-2846

11. Polur I, Lee PL, Servais JM, Xu L, Li Y: Role of HTRA1, a serine protease, in the progression of articular cartilage degeneration. Histol Histopathol 2010, 25:599-608

12. Ikawati M, Kawaichi M, Oka C: Loss of HtrAl serine protease induces synthetic modulation of aortic vascular smooth muscle cells. PLoS One 2018, 13:e0196628

13. Bouxsein ML, Boyd SK, Christiansen BA, Guldberg RE, Jepsen KJ, Muller R: Guidelines for assessment of bone microstructure in rodents using micro-computed tomography. J Bone Miner Res 2010, 25:1468-1486

14. Hildebrand T, Laib A, Muller R, Dequeker J, Ruegsegger P: Direct three-dimensional morphometric analysis of human cancellous bone: 
microstructural data from spine, femur, iliac crest, and calcaneus. J Bone Miner Res 1999, 14:1167-1174

15. Hildebrand T, Rüegsegger P: A new method for the model independent assessment of thickness in three-dimensional images. J Microsc 1997, 185:67-75

16. Hildebrand T, Rüesegger P: Quantification of bone microarchitecture with the structure model index. Comput Methods Biomech Biomed Engin 1997, 1:5-23

17. Glasson SS, Chambers MG, Van Den Berg WB, Little CB: The OARSI histopathology initiative: recommendations for histological assessments of osteoarthritis in the mouse. Osteoarthritis Cartilage 2010, 18 Suppl 3:S17-S23

18. Xu L, Polur I, Servais JM, Hsieh S, Lee PL, Goldring MB, Li Y: Intact pericellular matrix of articular cartilage is required for unactivated discoidin domain receptor 2 in the mouse model. Am J Pathol 2011, 179:1338-1346

19. Poole CA, Ayad S, Schofield JR: Chondrons from articular cartilage, I: immunolocalization of type VI collagen in the pericellular capsule of isolated canine tibial chondrons. J Cell Sci 1988, 90:635-643

20. Graham JR, Chamberland A, Lin Q, Li XJ, Dai D, Zeng W, Ryan MS, Rivera-Bermúdez MA, Flannery CR, Yang Z: Serine protease HTRA1 antagonizes transforming growth factor- $\beta$ signaling by cleaving its receptors and loss of HTRA1 in vivo enhances bone formation. PLoS One 2013, 8:e74094

21. Lee JH, Fitzgerald JB, Dimicco MA, Grodzinsky AJ: Mechanical injury of cartilage explants causes specific time-dependent changes in chondrocyte gene expression. Arthritis Rheum 2005, 52:2386-2395

22. Albro MB, Cigan AD, Nims RJ, Yeroushalmi KJ, Oungoulian SR, Hung CT, Ateshian GA: Shearing of synovial fluid activates latent TGF-ß. Osteoarthritis Cartilage 2012, 20:1374-1382

23. Xu L, Golshirazian I, Asbury BJ, Li Y: Induction of high temperature requirement $\mathrm{A} 1$, a serine protease, by TGF-betal in articular chondrocytes of mouse models of OA. Histol Histopathol 2014, 29: 609-618

24. Chen R, Mian M, Fu M, Zhao JY, Yang L, Li YF, Xu L: Attenuation of the progression of articular cartilage degeneration by inhibition of Tgf- $\beta 1$ signaling in a mouse model of osteoarthritis. Am J Pathol 2015, 185:2875-2885

25. Bakker AC, van de Loo FA, van Beuningen HM, Sime P, van Lent PL, van der Kraan PM, Richards CD, van den Berg WB: Overexpression of active TGF-beta-1 in the murine knee joint: evidence for synovial-layer-dependent chondro-osteophyte formation. Osteoarthritis Cartilage 2001, 9:128-136

26. Zhen G, Wen C, Jia X, Li Y, Crane JL, Mears SC, Askin FB, Frassica FJ, Chang W, Yao J, Carrino JA, Cosgarea A, Artemove D, Chen Q, Zhao Z, Zhou X, Riley L, Sponseller P, Wan M, Lu WW, Cao X: Inhibition of TGF-beta signaling in mesenchymal stem cells of subchondral bone attenuates osteoarthritis. Nat Med 2013, 19:704-712

27. Kawamura I, Maeda S, Imamura K, Setoguchi T, Yokouchi M, Ishidou Y, Komiya S: SnoN suppresses maturation of chondrocytes by mediating signal cross-talk between transforming growth factorbeta and bone morphogenetic protein pathways. J Biol Chem 2012 , 287:29101-29113

28. Schlaak JF, Pfers I, Meyer Zum Buschenfelde KH, MarkerHermann E: Different cytokine profiles in the synovial fluid of patients with osteoarthritis, rheumatoid arthritis and seronegative spondylarthropathies. Clin Exp Rheumatol 1996, 14:155-162

29. Aref-Eshghi E, Liu M, Harper PE, Dore J, Martin G, Furey A, Green R, Rahman P, Zhai G: Overexpression of MMP13 in human osteoarthritic cartilage is associated with the SMAD-independent TGF-beta signalling pathway. Arthritis Res Ther 2015, 17:264

30. Thomas M, Fronk Z, Gross A, Willmore D, Arango A, Higham C, Nguyen V, Lim H, Kale V, McMillan G, Seegmiller RE: Losartan attenuates progression of osteoarthritis in the synovial temporomandibular and knee joints of a chondrodysplasia mouse model through inhibition of TGF- $\beta 1$ signaling pathway. Osteoarthritis Cartilage 2019, 27:676-686

31. Urano T, Narusawa K, Kobayashi S, Shiraki M, Horie-Inoue K, Sasaki N, Hosoi T, Ouchi Y, Nakamura T, Inoue S: Association of HTRA1 promoter polymorphism with spinal disc degeneration in Japanese women. J Bone Miner Metab 2010, 28:220-226

32. Poole CA, Flint MH, Beaumont BW: Chondrons extracted from canine tibial cartilage: preliminary report on their isolation and structure. J Orthop Res 1988, 6:408-419

33. Hunziker EB, Michel M, Studer D: Ultrastructure of adult human articular cartilage matrix after cryotechnical processing. Microsc Res Tech 1997, 37:271-284

34. Tiaden AN, Richards PJ: The emerging roles of HTRA1 in musculoskeletal disease. Am J Pathol 2013, 182:1482-1488

35. Guilak F, Nims RJ, Dicks A, Wu CL, Meulenbelt I: Osteoarthritis as a disease of the cartilage pericellular matrix. Matrix Biol 2018, 71-72: $40-50$

36. Xu L, Peng H, Wu D, Hu K, Goldring MB, Olsen BR, Li Y: Activation of the discoidin domain receptor 2 induces expression of matrix metalloproteinase 13 associated with osteoarthritis in mice. J Biol Chem 2005, 280:548-555

37. Xu L, Peng H, Glasson S, Lee PL, Hu K, Ijiri K, Olsen BR, Goldring MB, Li Y: Increased expression of a collagen receptor discoidin domain receptor 2 in articular cartilage as a key event in the pathogenesis of osteoarthritis. Arthritis Rheum 2007, 56: $2663-2673$

38. Sunk IG, Bobacz K, Hofstaetter JG, Amovo L, Soleiman A, Smolen J, Xu L, Li Y: Increased expression of discoidin domain receptor 2 is linked to the degree of cartilage damage in human knee joints: a potential role in osteoarthritis pathogenesis. Arthritis Rheum 2007, 56:3685-3692

39. Xu L, Servais J, Polur I, Kim D, Lee PL, Chung K, Li Y: Attenuation of osteoarthritis progression by reduction of the discoidin domain receptor 2 in mice. Arthritis Rheum 2010, 62:2736-2744

40. Manning LB, Li Y, Chickmagalur NS, Li X, Xu L: Discoidin domain receptor 2 as a potential therapeutic target for development of diseasemodifying osteoarthritis drugs. Am J Pathol 2016, 186:3000-3010

41. Klatt AR, Zech D, Kühn G, Paul-Klausch B, Klinger G, Renno JH, Schmidt J, Malchau G, Wielckens K: Discoidin domain receptor 2 mediates the collagen II-dependent release of interleukin-6 in primary human chondrocytes. J Pathol 2009, 218:241-247

42. Vonk LA, Doulabi BZ, Huang C, Helder MN, Everts B, Bank RA: Collagen-induced expression of collagenase-3 by primary chondrocytes is mediated by integrin $\alpha 1$ and discoidin domain receptor 2 : a protein kinase C-dependent pathway. Rheumatology (Oxford) 2011, 50:463-472

43. Holt DW, Henderson ML, Stockdale CE, Farrell JT, Kooyman DL, Bridgewater LC, Seegmiller RE: Osteoarthritis-like changes in the heterozygous sedc mouse associated with the HtrA1-Ddr2-Mmp-13 degradative pathway: a new model of osteoarthritis. Osteoarthritis Cartilage 2012, 20:430-439

44. Siim Suutre S, Kerna I, Lintrop M, Tamm H, Aunapuu M, Arend A, Tamm A: Evaluation of correlation of articular cartilage staining for DDR2 and proteoglycans with histological tissue damage and the results of radiographic assessment in patients with early stages of knee osteoarthritis. Int J Clin Exp Pathol 2015, 8:5658-5665

45. Cabrera AC, Melo E, Roth D, Topp A, Delobel F, Stucki C, Chen CY, Jakob P, Banfai B, Dunkley T, Schilling O, Huber S, Iacone R, Petrone P: HtrA1 activation is driven by an allosteric mechanism of inter-monomer communication. Sci Rep 2017, 7: 14804 